\title{
Gene Expression of Immunologically Important Factors in Blood Cells, Milk Cells, and Mammary Tissue of Cows
}

\author{
M. W. Pfaffl, S. L. Wittmann, H. H. D. Meyer, and R. M. Bruckmaier \\ Institute of Physiology, \\ Technical University Munich, \\ Weihenstephaner Berg 3, D-85350 Freising, Germany
}

\section{ABSTRACT}

Cytokines, eicosanoids, and lactoferrin are involved in the mammary gland's immune response to invading microorganisms. The goal of this work was to investigate the synthesis of these immunologically important factors in somatic milk cells, blood cells, and mammary tissue of cows with different somatic cell count levels, i.e., different immunological activity. On the level of mRNA expression, the cytokine tumor necrosis factor $\alpha(\mathrm{TNF} \alpha)$, lactoferrin (Lf), and specific key enzymes of leukotriene and prostaglandin biosynthesis, 5 -lipoxygenase (5-LO), and cyclooxygenase-1 (COX-1) and -2 (COX-2), respectively, were determined. All 15 experimental cows were clinically healthy with no visible mammary disease. Eight cows were defined as control group with all quarters $<150,000$ cells $/ \mathrm{ml}$ (C), whereas seven cows had partially elevated quarter somatic cell counts, with at least one quarter $>150,000$ cells $/ \mathrm{ml}(\mathrm{H})$ and one quarter $<150,000$ cells $/ \mathrm{ml}(\mathrm{L})$. Total quarter milk from one quarter of control group and from two quarters of cows with partially elevated cell counts (one of $\mathrm{H}$ and one of $\mathrm{L}$ ) was collected at one milking and a blood sample was taken simultaneously. In addition, mammary tissue samples were taken from the respective quarters on the following day during slaughter. Total RNA from milk, blood, and tissue cells was isolated and reverse transcription and quantitative polymerase chain reaction was carried out. All factors investigated were not significantly different between groups in blood cells and between $\mathrm{C}$ and L quarters in milk cells and mammary tissue. $\mathrm{TNF} \alpha$ and COX-2 mRNA expression was higher in milk cells and mammary tissue of $\mathrm{H}$ than in $\mathrm{L}$ quarters, except for COX-2 in mammary tissue. Generally, $\mathrm{TNF} \alpha$ and COX-2 showed their highest expression in milk cells, 5-LO in blood cells, whereas lactoferrin was

Received December 21, 2001.

Accepted April 8, 2002.

Corresponding author: R. M. Bruckmaier; e-mail: bruckmaier@ wzw.tum.de. mainly expressed by the mammary tissue. COX-1 was similarly expressed in all tested samples.

(Key words: Mammary gland, immunology, eicosanoid, tumor necrosis factor alpha)

Abbreviation key: COX-1 = cyclooxygenase-1, COX$\mathbf{2}=$ cyclooxygenase $-2, \mathbf{g D N A}=$ genomic $\mathrm{DNA}, \mathbf{L f}=$ lactoferrin, 5-LO $=$ 5-lipoxygenase, $\mathbf{R T}=$ reverse transcription, RT-PCR = reverse transcription - quantitative polymerase chain reaction, $\mathbf{T N F} \boldsymbol{\alpha}=$ tumor necrosis factor alpha, UbC = ubiquitin.

\section{INTRODUCTION}

Elevated somatic cell counts (SCC) in cow milk are a sign of increased immunological activity due to invasion of microorganisms, which may result in clinical or subclinical mastitis. A better understanding of the pathophysiological mechanisms of immune response expressed at a subclinical level may lead to new strategies of breeding and therapy.

Different factors are known to support natural defense mechanisms of the mammary gland against invading microorganisms. Inflammatory mediators, including cytokines, prostaglandins, and leukotrienes exert potent chemokinetic and chemotactic activity on leukocytes (Craven, 1986; Heidel et al., 1989; Rose et al., 1989; Persson et al., 1993) and enhance the bactericidal activity of phagocytes in dairy cows (Sanchez et al., 1994). Moreover, they are involved in the vascular permeability and hyperalgesia associated with mastitis (Zia et al., 1987; Koenig et al., 1990). The iron-binding glycoprotein lactoferrin (Lf) has been shown to be bacteriostatic for a variety of microorganism, as a result of making iron unavailable to the organisms (Bullen et al., 1978). Furthermore, Lf may directly kill bacteria or weaken their resistance, by adhesion to their surface (Arnold et al., 1977, 1980).

Detection of these factors is possible at the proteinencoding mRNA level by reverse transcription (RT) polymerase chain reaction (PCR). The mRNA of $\mathrm{Lf}$ and cytokines, like tumor necrosis factor alpha ( TNF $\boldsymbol{\alpha}$ ), can be determined with RT-PCR. The synthesis of prostaglandins and leukotrienes can be esti- 
mated via the mRNA expression of specific key enzymes of their synthetic pathways, i.e., cyclooxygenase-1 (COX-1, a constitutive enzyme), cyclooxygenase-2 (COX-2, an inducible enzyme) and 5-lipoxygenase (5-LO) (Ford-Hutchinson et al., 1994; Smith and Dewitt, 1996).

The goal of this work was to test the hypothesis that these factors are differently expressed in somatic milk cells, blood cells, and mammary tissue of cows with different SCC levels, i.e., different immunological activity, but without signs of clinical mastitis. Therefore, we developed a quantitative real-time RT-PCR, using an external calibration curve, to determine the mRNA expression of COX-1, COX-2, 5-LO, TNF $\alpha$, Lf, and the housekeeping gene ubiquitin (UbC).

\section{MATERIALS AND METHODS}

\section{Animals and Sample Collection}

Fifteen dairy cows (seven Red Holstein, four Holstein Friesian, and four Brown Swiss) with no clinical signs of mammary disease were used. Experimental cows were in their first to sixth lactation. Total quarter milk SCC were measured with a fluoro-opto-electronic method using a Fossomatic 5000 cell counter (Foss Electric, Hillerød, Denmark). Cows were defined as control group $(n=8)$, if all quarters had $<150,000$ cells/ $\mathrm{ml}(\mathrm{C}=$ control $)$ and as group with partially elevated quarter SCC $(\mathrm{n}=7)$, if at least one quarter had $>150,000$ cell $/ \mathrm{ml}(\mathrm{H}=$ high $)$ and at least one quarter had $<150,000$ cells $/ \mathrm{ml}(\mathrm{L}=$ low). Total quarter milk from one quarter of control group cows and from two quarters of cows with partially elevated SCC (one of $\mathrm{H}$ and one of $\mathrm{L}$ ) was collected at one milking. Immediately after milking, $50 \mathrm{ml}$ of blood was taken from a jugular vein and coagulation was prevented by EDTA. On the next day, cows were slaughtered and mammary tissue from the quarters used for milk samples before was collected, trimmed free of large pieces of connective and adipose tissue, and immediately frozen in liquid nitrogen.

\section{Milk Cell Isolation and Viability Test}

The milk (minimum $1 \mathrm{~L}$ ) was centrifuged for $30 \mathrm{~min}$ in $175-\mathrm{ml}$ tubes at $220 \mathrm{~g}$. The cell pellet was washed in PBS pH 7.4 and centrifuged for $15 \mathrm{~min}$ at $4^{\circ} \mathrm{C}$ and $220 \times g$ according to Liebe (1996). Viability of the collected cells was 60 to $80 \%$, assessed by trypan blue staining and counting in a Neubauer's counting chamber (Brand, Wertheim, Germany).

\section{Blood Cell Isolation and Cell Ratio Evaluation}

Twenty milliliters of blood, anticoagulated with EDTA, was mixed with lysis buffer $\left(830 \mathrm{mg}\right.$ of $\mathrm{NH}_{4} \mathrm{Cl}$; $3.7 \mathrm{mg}$ of Na-EDTA; $100 \mathrm{mg}$ of $\mathrm{KCl}$; in $100 \mathrm{ml}$ of $\mathrm{H}_{2} \mathrm{O}$ at $\mathrm{pH}$ 7.4) and centrifuged for $10 \mathrm{~min}$ in 50-ml Falcon tubes at $220 \times g$. The cell pellet was again suspended in lysis buffer and centrifugation was repeated. Viability of the collected cells was 70 to $95 \%$.

\section{RNA Isolation and cDNA Synthesis}

Total RNA of milk cells, blood cells and mammary tissue was isolated using TriPure (Roche Diagnostics, Basle, Switzerland) according to manufacturers instructions. To quantify the extracted RNA, the optical density was determined at three different dilutions of the final total RNA preparations of $260 \mathrm{~nm}$. RNA integrity was verified by ethidium bromide stained gel electrophoresis (Figure 1) and by optical density $\mathrm{OD}_{260 \mathrm{~nm}} / \mathrm{OD}_{280 \mathrm{~nm}}$ absorption ratio $>1.65$. Synthesis of first strand DNA was performed with reverse transcriptase (MMLV-RT, Promega, Madison, WI) and random hexamer primers (MBI Fermentas, St. LeonRot, Germany) according to the manufacturers instructions. UbC was chosen to confirm a constant gene expression level in the investigated total RNA extractions derived from the different samples.

\section{Oligonucleotide Primers}

To demonstrate the amplification of only the cDNA but not the genomic DNA (gDNA) the sense and antisense primers of every target gene were placed in two different exons of the gene. Therefore, the respective lengths of the PCR products of cDNA and gDNA differed. The different primers were designed using published bovine nucleic acid sequences. All necessary primer information are listed in Table 1. To confirm specificity of real-time RT-PCR assays, the derived RT-PCR products were sequenced (Toplab, Martinsried, Germany) and 100\% homology to the published sequences was given (Wittmann et al., 2002).

\section{Bacteriological Investigation}

Milk samples were cultured bacteriologically at the lab of the Animal Health Service Bavaria, Germany. Isolated bacteria were identified according to the standards of the German Veterinary Medical Society (2000).

\section{Quantification by Real-Time PCR}

Quantitative analysis of PCR products was carried out in the LightCycler (Roche Diagnostics) using ex- 


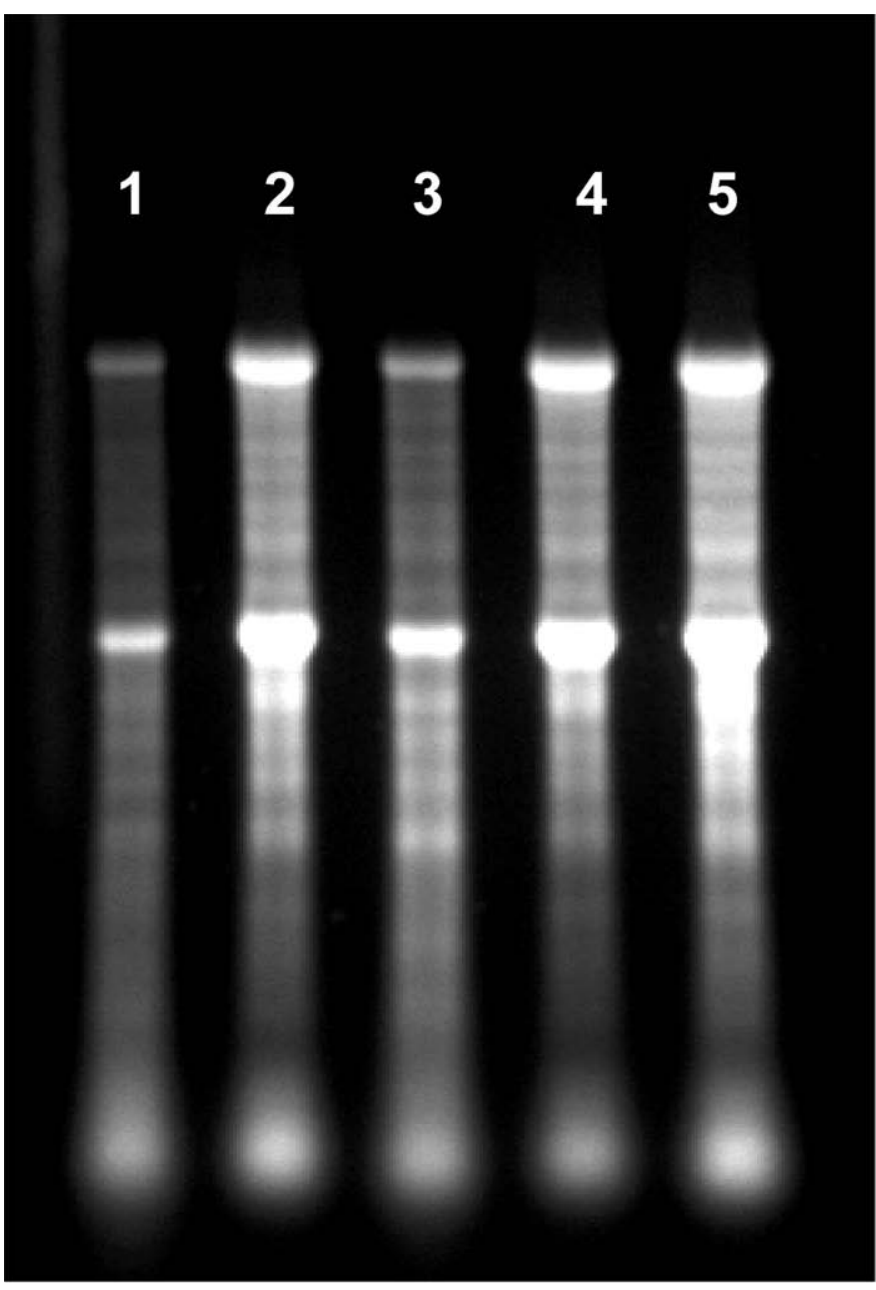

Figure 1. Integrity check on denaturated agarose gel of $3 \mu \mathrm{g}$ of total RNA per lane extracted from either milk cells (lanes 1 to 3 ) or mammary tissue (lanes 4 and 5).

ternal plasmid DNA standard dilutions (recDNA) derived from cloned specific cDNA fragments of COX-1, COX-2, TNF $\alpha, 5-\mathrm{LO}$, and Lf according to the method described (Pfaffl and Hageleit, 2001).

Two microliters of reversely transcribed total RNA $(10 \mathrm{ng} / \mu \mathrm{l})$ were used as PCR template. Further reaction components for the LightCycler reactions were $1.2 \mu \mathrm{l}$ of $\mathrm{MgCl}_{2}(4 \mathrm{mM}), 0.2 \mu \mathrm{L}$ of forward primer $(0.4$ $\mu M), 0.2 \mu \mathrm{l}$ of reverse primer $(0.4 \mu M), 1.0 \mu \mathrm{l}$ of LightCycler DNA Master SYBR Green I (Roche Diagnostics) and water up to a final volume of $10 \mu \mathrm{l}$. Minor modification for COX-2 assay were performed: a reduction of $\mathrm{MgCl}_{2}$ to a final concentration of $3 \mathrm{mM}$ and of forward/reverse primer to $0.2 \mu M$. In the case of COX1 , COX-2, and Lf, the reaction was optimized by an additional $0.1 \mu \mathrm{l}(0.5 \mathrm{U})$ of Taq DNA polymerase (Roche Diagnostics).
Before amplification, an initial denaturation step $\left(30 \mathrm{~s}\right.$ at $\left.95^{\circ} \mathrm{C}\right)$ was performed to ensure complete denaturation of the cDNA. LightCycler PCR was performed with 50 cycles and product-specific PCR cycle conditions are listed in Table 2 . To each amplification cycle a fourth segment with an elevated temperature fluorescence acquisition point was added to remove unspecific signals before SYBR Green I quantification. Thus, only the specific PCR products were quantified. Amplified PCR products underwent a melting curve analysis after the last cycle to specify the integrity of amplification and finally a cooling step was performed.

To verify the specificity of each LightCycler PCR quantification system and to generate cDNA standards the LightCycler RT-PCR products were cloned into pCR 4.0 vector (Invitrogen, Groningen, The Netherlands) and sequenced (Toplab and MWG Biotech, Ebersberg, Germany).

\section{Statistical Evaluations}

Differences between $\mathrm{C}$ and L quarters (blood L\&H quarters) were tested for significance $(P<0.05)$ using Wilcoxon's rank sum test of the NPAR1WAY procedure of SAS (SAS 6.11). Differences between L and H quarters (within animal) were tested for significance $(P<0.05)$ by Wilcoxon's signed rank test of the UNIVARIATE procedure of SAS.

\section{RESULTS}

\section{Real-Time RT-PCR Validation}

Specificity of the desired products and expected RTPCR product length in bovine total RNA were documented with agarose gel electrophoresis (Figure 2) and additionally with melting curve analysis. The sensitivity of the LightCycler RT-PCR was evaluated us-

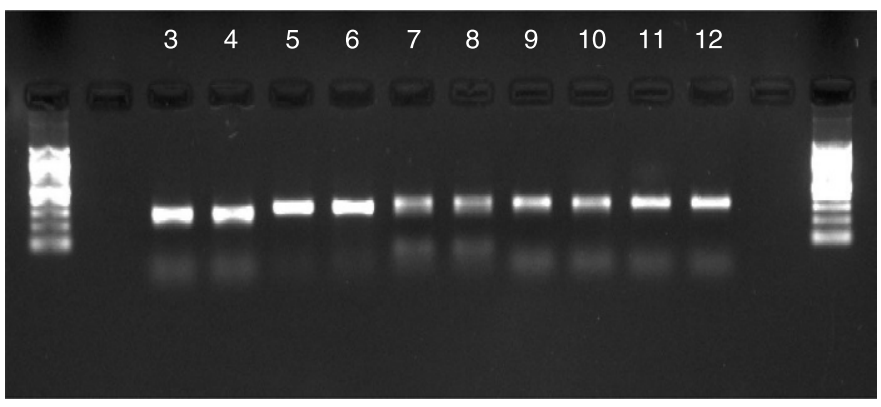

Figure 2. Agarose gel electrophoresis of TNF $\alpha$ (277 bp), COX-1 (313 bp), COX-2 (359 bp), Lf (338 bp), and 5-LO (332 bp) duplicate (lanes 3 to 12 from left to right) real-time RT-PCR product from either milk cells or mammary gland. In first and last lane a 100-bp length standard is shown. 


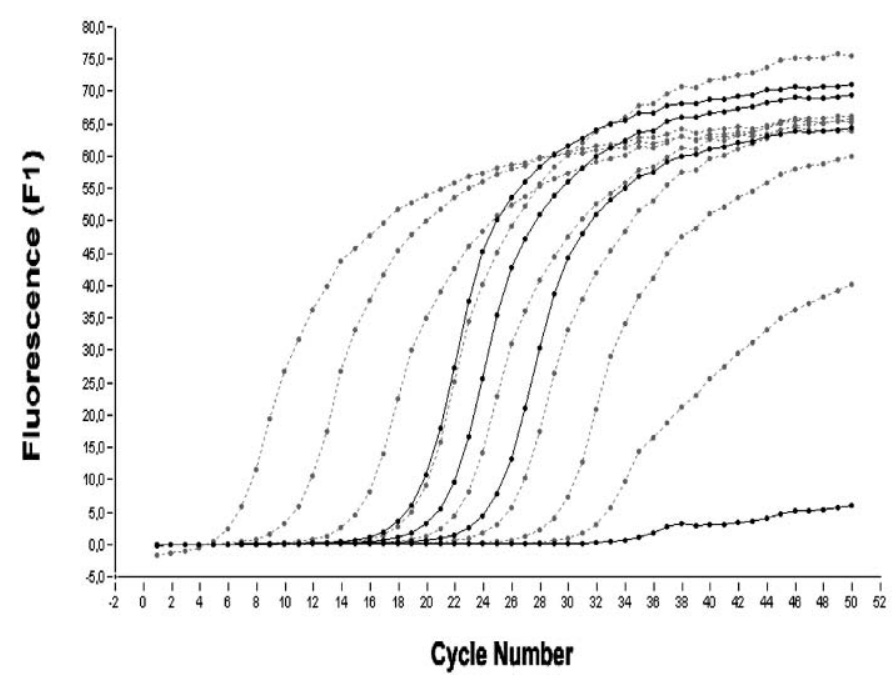

Figure 3. Quantitative TNF $\alpha$ real-time RT-PCR run on LightCycler platform. Kinetic RT-PCR standard curves from $5.6 \times 10^{8}$ to 56 (from left to right) $\mathrm{TNF} \alpha$ recombinant single stranded DNA molecules are shown in dotted lines (--•--). Biological samples from milk cells, blood cells and mammary tissue as well as negative water control (bottom line) are shown in solid lines (—•-).

ing different starting amounts of recDNA (Table 3). In all assays the sensitivity of the quantification was very high, i.e., six recDNA $\mathrm{TNF} \alpha$ molecules present in the capillary could be detected. The SYBR Green I determination at elevated temperatures resulted in a reliable and sensitive quantification with high test linearity (Pearson correlation coefficient $r>0.995$ ) over seven orders of magnitude from $<10^{3}$ to $>10^{9}$ recDNA start molecules. $\mathrm{TNF} \alpha$ real-time PCR history using recDNA standard curve and three biological samples cDNA are shown in Figure 3. Real-time PCR efficiencies were calculated from the given slopes in LightCycler Software 3.3 (Roche Diagnostics). The corresponding real-time PCR efficiency (E) of one cycle in the exponential phase was calculated according to the equation: $\mathrm{E}=10^{[-1 / \mathrm{slope}]}$. The maximal efficiency of PCR is $\mathrm{E}=2$ where every PCR product is replicated every cycle and the minimal value is $\mathrm{E}=1$, corresponding to no replication. Investigated transcripts showed real-time PCR efficiency rates between 1.73 for 5-LO and 1.95 for COX-2 (Table 3). Acquisition of interassay variation were performed at minimum three different days. Variations were calculated over the entire quantification range of seven orders of magnitude on molecule basis and resulted in sufficiently low variation under $30 \%$ (Table 3 ).

\section{Mean SCC, Bacteria in Milk, and Ubiquitin mRNA Expression}

Mean SCC were $57 \pm 20$ and $64 \pm 18 \times 10^{3} / \mathrm{ml}$ in C and L quarters, respectively, and significantly higher by definition in $\mathrm{H}$ quarters $\left(445 \pm 143 \times 10^{3} / \mathrm{ml}\right)$.
Bacteria isolated from milk of the $\mathrm{H}$ quarters included Staphylococcus aureus (three cases), other Staphylococci (one case), aesculin-positive Streptococci (one case), and coliforms (one case). In one case, no pathogens could be detected in the $\mathrm{H}$ quarter. From the milk of $\mathrm{L}$ quarters, in one case coliforms were isolated and from the milk of $\mathrm{C}$ quarters in one case Staphylococci (not $S$. aureus) and in one other case aesculin-positive Streptococci were isolated. In the milk of all other $\mathrm{L}$ and $\mathrm{C}$ quarters no pathogens could be detected.

Absolute UbC mRNA expression levels were quantified and based on the average UbC mRNA expression $(=100 \%)$ measured in all samples $(\mathrm{n}=59)$. In blood cells, UbC mRNA expression was $83.9 \%$ in the group with partially elevated quarter SCC and $87.4 \%$ in the control group. In milk cells, expression was $236.7 \%$ in $\mathrm{H}$ quarters, $143.9 \%$ in L quarters and $120.2 \%$ in $\mathrm{C}$ quarters. In mammary tissue, the absolute expression was $46.4 \%$ in $\mathrm{H}$ quarters, $47.1 \%$ in $\mathrm{L}$ quarters and $41.5 \%$ in $\mathrm{C}$ quarters.

Expression of mRNA of the tested factors was normalized according to the UbC relative mRNA expression of each sample compared with the other samples derived from blood cells, milk cells or mammary tissue, respectively. The correction was performed only within tissue types. Mean correction factor for blood cells $97.8 \%$ in the group with partially elevated quarter SCC and $101.9 \%$ in the control group. In milk cells, mean correction factor was $143.6 \%$ in $\mathrm{H}$ quarters, $87.3 \%$ in $\mathrm{L}$ quarters, and $72.9 \%$ in $\mathrm{C}$ quarters and in mammary tissue, it was $103.4 \%$ in $\mathrm{H}$ quarters, $105.1 \%$ in L quarters, and $92.5 \%$ in C quarters. No correction was performed between tissue types: blood cell, milk cell and mammary tissue samples.

\section{Expression of mRNA in Blood Cells, Milk Cells, and Mammary Tissue}

Expression of mRNA in blood cells, milk cells, and in mammary gland of group with partially elevated quarter SCC and of control group for COX-1, COX-2, 5 -LO, $\mathrm{TNF} \alpha$, and Lf are listed in Table 4. Comparing these mRNA expression levels in blood cells, no significant differences between experimental groups.

The mRNA expressions in milk cells were similar in $\mathrm{L}$ and $\mathrm{C}$ quarters for all factors tested. Only mRNA expression of $\mathrm{TNF} \alpha$ calculated for one cell was significantly higher in L quarters compared with $\mathrm{C}$ quarters. Expression of COX-2 and Lf mRNA were significantly higher in $\mathrm{H}$ compared to $\mathrm{C}$ or $\mathrm{L}$ quarters.

Expression of mRNA in mammary tissues were not significantly different between $\mathrm{L}$ and $\mathrm{C}$ quarters. 
PFAFFL ET AL.

Table 1. Sequences of PCR primers (forward: for and reverse: rev), position in coding sequence (CDS), PCR product length and GenBank and EMBL accession number of the used published bovine nucleic acid sequences.

\begin{tabular}{lllll}
\hline Gene & Primer sequence $\left(5^{\prime} \rightarrow 3^{\prime}\right)$ & CDS & Length & EMBL no. \\
\hline COX-1 for & AGATGCGGAGTTTCTGAGTCG & 156 & $313 \mathrm{bp}$ & AF004943 \\
COX-1 rev & GGGTAGTGCATCAGCACGG & 467 & & (partial CDS) \\
COX-2 for & CTCTTCCTCCTGTGCCTGAT & 410 & $359 \mathrm{bp}$ & AF031698 \\
COX-2 rev & CTGAGTATCTTTGACTGTGGGAG & 768 & & \\
TNF $\alpha$ for & TAACAAGCCGGTAGCCCACG & 255 & & AF011926 \\
TNF $\alpha$ rev & GCAAGGGCTCTTGATGGCAGA & 531 & & \\
5 -LO for & GCCCTTCTACAACGACTTCGA & 120 & & AJ306424 \\
5 -LO rev & CAGGGTTCCACTCCATCCA & 451 & & \\
Lf for & GGCCTTTGCCTTGGAATGTATC & 174 & & L08604 \\
Lf rev & ATTTAGCCACAGCTCCCTGGAG & 511 & $338 \mathrm{bp}$ & \\
UbC for & ATGCAGATCTTTGTGAAGAC & 1 & & Z18245 \\
UbC rev & CTTCTGGATGTTGTAGTC & 189 & & \\
\hline
\end{tabular}

mRNA expression of $\mathrm{TNF} \alpha$ was significantly higher in $\mathrm{H}$ than in $\mathrm{C}$ or $\mathrm{L}$ quarters.

\section{Absolute Expression Levels of mRNA in Tissue Types}

Comparing the absolute expression levels in $20 \mathrm{ng}$ of total RNA for blood cells, milk cells, and mammary tissue (Table 4), the highest mRNA expressions were found for 5-LO in blood cells, for COX-2 and TNF $\alpha$ in milk cells and for Lf in mammary tissue. For COX-1 mRNA expressions were rather similar.

\section{DISCUSSION}

Somatic cells in milk consist of macrophages, lymphocytes, neutrophils, and mammary epithelial cells. The amount of milk SCC is an indicator for the health of the mammary gland. As a response to invading microorganisms, milk SCC and thus the immunological activity increase (Kehrli and Schuster, 1994). In this work quarters with SCC $>150,000$ cells/ml were defined as quarters with increased immunological activity. Based on this criterion blood, milk, and mammary tissue samples were collected.

For our investigation, factors were selected that are known to be involved in natural defense mechanisms of the mammary gland against invading microorganisms. TNF $\alpha$ as an acute phase cytokine modulates many host reactions to foreign antigens, like phagocytosis or recruitment of leukocytes by their chemotactic activity and by elevated expression of adhesion molecules on circulating leukocytes and endothelial cells (Shuster et al., 1993; Sanchez et al., 1994). The early increase of TNF $\alpha$ during Escherichia coli mastitis was documented by several studies (Shuster et al., 1993; Sordillo et al., 1997; Blum et al., 2000). Also, in this study significantly higher mRNA expressions were found in milk cells and mammary tissue of the $\mathrm{H}$ quarters, i.e., the quarters with increased immunological activity, than in L and C quarters. Expression levels were about 500-fold higher in milk cells, than in mam-

Table 2. Product specific LightCycler PCR conditions.

\begin{tabular}{|c|c|c|c|c|c|c|c|c|}
\hline \multirow{2}{*}{\multicolumn{2}{|c|}{ No. segment }} & \multirow{3}{*}{$\frac{\text { Duration }(\mathrm{s})}{5}$} & \multicolumn{6}{|c|}{ Target temperature $\left({ }^{\circ} \mathrm{C}\right)$} \\
\hline & & & \multirow{2}{*}{$\begin{array}{l}\text { COX-1 } \\
95\end{array}$} & \multirow{2}{*}{$\begin{array}{l}\text { COX-2 } \\
95\end{array}$} & \multirow{2}{*}{$\frac{\mathrm{TNF} \alpha}{95}$} & \multirow{2}{*}{$\begin{array}{l}5-\mathrm{LO} \\
95\end{array}$} & \multirow{2}{*}{$\frac{\mathrm{Lf}}{95}$} & \multirow{2}{*}{$\frac{\mathrm{UbC}}{95}$} \\
\hline I & denaturation & & & & & & & \\
\hline II & product specific annealing & 10 & 70 & 67 & 64 & 64 & 68 & 55 \\
\hline III & elongation & 25 & 72 & 72 & 72 & 72 & 72 & 72 \\
\hline IV & fluorescence acquisition & 3 & 84 & 80 & 86 & 85 & 86 & 82 \\
\hline
\end{tabular}


Table 3. Characteristics and validation parameters of $\mathrm{TNF} \alpha, \mathrm{COX}-1, \mathrm{COX}-2$, Lf and 5-LO real-time RTPCR on LightCycler platform. ${ }^{1}$

\begin{tabular}{llllll}
\hline & $\mathrm{TNF} \alpha$ & $\mathrm{COX}-1$ & $\mathrm{COX}-2$ & $\mathrm{Lf}$ & 5 -LO \\
\hline Product length & $277 \mathrm{bp}$ & $313 \mathrm{bp}$ & $359 \mathrm{bp}$ & $338 \mathrm{bp}$ & $332 \mathrm{bp}$ \\
Detection limit & $6 \mathrm{~m}$ & $310 \mathrm{~m}$ & $205 \mathrm{~m}$ & $26 \mathrm{~m}$ & $20 \mathrm{~m}$ \\
Quantification limit & $56 \mathrm{~m}$ & $3100 \mathrm{~m}$ & $2050 \mathrm{~m}$ & $255 \mathrm{~m}$ & $56 \mathrm{~m}$ \\
Quantification range & $5.6 * 10^{9} \mathrm{~m}$ & $3.1 * 10^{10} \mathrm{~m}$ & $2.0 * 10^{9} \mathrm{~m}$ & $2.5 * 10^{10} \mathrm{~m}$ & $2.0^{*} 10^{9} \mathrm{~m}$ \\
(test linearity) & $(\mathrm{r}=0.998)$ & $(\mathrm{r}=0.995)$ & $(\mathrm{r}=0.996)$ & $(\mathrm{r}=0.998)$ & $(\mathrm{r}=0.998)$ \\
PCR efficiency & 1.92 & 1.75 & 1.95 & 1.93 & 1.73 \\
Inter-assay variation & $21.6 \%(\mathrm{n}=4)$ & $29.3 \%(\mathrm{n}=6)$ & $27.3 \%(\mathrm{n}=4)$ & $21.6 \%(\mathrm{n}=3)$ & $26.5 \%(\mathrm{n}=4)$ \\
\hline
\end{tabular}

${ }^{1} \mathrm{~m}=$ Molecules per capillary, $\mathrm{r}=$ Pearson correlation coefficient.

mary tissue. This finding identifies milk cells as an important and major source for $\mathrm{TNF} \alpha$ in the fight against invading microorganisms. No significant group differences in white blood cells confirm observations that $\mathrm{TNF} \alpha$ in serum increases only during severe mastitis and not during milk or subclinical mastitis (Shuster et al., 1993; Nakajima et al., 1997). For this reason, the responses in blood cells will have been insignificant also for the other factors tested.

Other important inflammatory mediators are prostaglandins and leukotrienes, i.e., metabolites of the arachidonic acid. They are involved in several events during acute and chronic inflammatory disorders, such as increasing vascular permeability, chemotaxis, and hyperalgesia (Craven, 1986; Zia et al., 1987; Heidel et al., 1989; Rose et al., 1989; Koenig et al., 1990; Persson et al., 1993). The estimation of prostaglandins and leukotrienes was made via the mRNA expression of specific key enzymes of their synthetic pathways. The key enzyme in leukotriene synthesis is 5-LO. Its mRNA expression tend to increase in $\mathrm{H}$ quarters compared with L quarters but not significantly due to one animal. In our previous investigation 5 -LO in milk cells of quarters with increased immunological activity increase significantly (Wittmann et al., 2002). However, no significant differences between quarters were found in mammary tissue. Most likely milk cells are the most important source of 5-LO and, as a result, for leukotrienes in the udder.

Key enzymes in prostanoid (prostaglandins, prostacyclin, and thromboxanes) synthesis are COX-1 and COX-2. The two isoforms generate the same prostanoids, but COX-1 is constitutively expressed in almost all tissues and COX-2 is an inducible enzyme. Usually COX-2 is barely expressed, but it is transiently upregulated during inflammation (Smith and Dewitt, 1996; Crofford, 1997). In this study, mRNA expression of COX-1 was not significantly different between quarters. This is a confirmation of constitutive expression of COX-1. In contrast COX-2 mRNA expression in milk cells was significantly elevated in $\mathrm{H}$ quarters when compared with L quarters. A trend of elevated expression in $\mathrm{H}$ quarters was also found in mammary tissue, however not significant. Although clinical investigation of the tested $\mathrm{H}$ quarters did not result in visible signs of inflammatory processes, mRNA expression of COX-2 was already up-regulated as a result of the increased immunological activity.

The iron-binding glycoprotein Lf has been shown to be bacteriostatic for a variety of microorganisms, as a result of making iron unavailable to them (Bullen et al., 1978). Furthermore Lf may directly kill bacteria or weaken their resistance, by adhesion to their surface (Arnold et al., 1977, 1980). It is synthesized by

Table 4. COX-1, COX-2, 5-LO, and Lf mRNA expression (in $10^{3}$ molecules) per $20 \mathrm{ng}$ cDNA reverse transcribed from blood cell, milk cell, and mammary tissue total RNA ${ }^{1}$.

\begin{tabular}{lllrrrr}
\hline Sample & Quarters & COX-1 & COX-2 & 5-LO & TNF $\alpha$ & Lf \\
\hline Blood cells & C & $30.3 \pm 10.9$ & $22.1 \pm 8.5$ & $131.7 \pm 68.9$ & $36.0 \pm 10.6$ & $3.9 \pm 2.0$ \\
Milk cells & L \& H & $50.3 \pm 17.7$ & $70.2 \pm 35.3$ & $53.3 \pm 12.1$ & $43.9 \pm 12.7$ & $9.6 \pm 7.4$ \\
& C & $10.2 \pm 2.7$ & $173.3 \pm 49.3$ & $4.8 \pm 1.1$ & $329.2 \pm 114.4$ & $262.6 \pm 105.8$ \\
Mammary tissue & L & $11.3 \pm 4.5$ & $158.5 \pm 59.0$ & $9.9 \pm 3.4$ & $508.4 \pm 98.0$ & $233.9 \pm 49.7$ \\
& $\mathrm{H}$ & $9.7 \pm 4.0$ & $573.7 \pm 255.4^{*}$ & $18.3 \pm 7.7$ & $715.1 \pm 147.0$ & $102.3 \pm 22.8^{*}$ \\
& $\mathrm{~L}$ & $37.6 \pm 19.3$ & $7.4 \pm 4.6$ & $0.7 \pm 0.2$ & $0.4 \pm 0.2$ & $6600.3 \pm 3475.4$ \\
& $\mathrm{H}$ & $30.1 \pm 14.1$ & $9.3 \pm 6.1$ & $0.9 \pm 0.4$ & $0.3 \pm 0.1$ & $5458.6 \pm 2559.4$ \\
& & $33.1 \pm 17.0$ & $17.0 \pm 9.1$ & $0.5 \pm 0.2$ & $1.4 \pm 0.7^{*}$ & $6989.4 \pm 2249.6$ \\
\hline
\end{tabular}

${ }^{1} \mathrm{COX}-1$ = cyclooxygenase- $1, \mathrm{COX}-2=$ cyclooxygenase- $2,5-\mathrm{LO}=5$-lipoxygenase, $\mathrm{TNF} \alpha=$ tumor necrosis factor alpha, Lf $=$ lactoferrin.

*Means of quarters "L" and "H" are significantly different $(P<0.05)$. 
glandular epithelial cells (Masson et al., 1966) and neutrophils (Baggiolini et al., 1970). Investigations of the bovine mammary gland showed a clear increase of Lf in the milk of $E$. coli infected quarters when compared with that of uninfected quarters (Harmon et al., 1976). But even quarters with subclinical mastitis showed a significant elevation of Lf level compared with normal quarters (Kawai et al., 1999). Herein, no major increase of Lf mRNA expression in the mammary tissue of $\mathrm{H}$ quarters compared with $\mathrm{C}$ or $\mathrm{L}$ quarters could be shown. The rather small difference was not significant likely because in two animals SCC was only slightly higher in $\mathrm{H}$ than in $\mathrm{L}$ quarters, i.e., immunological activity of $\mathrm{H}$ quarters was not extremely enhanced. However, we could identify mammary tissue as the major source of Lf mRNA in all quarters. mRNA expression of Lf was more than 20 -fold higher in mammary tissue than in milk cells. It was previously shown that mammary secretory epithelial cells synthesize lactoferrin (Goodman and Schanbacher, 1991; Hurley and Rejman, 1993). Nevertheless, it has to be checked whether these results will be similar during severe inflammatory processes when SCC of infected quarters will increase rapidly. Harmon (1980) eliminated the polymorphonuclear neutrophil granulocytes as the major source for Lf. Looking on milk cell data, there was a significant decrease of Lf mRNA expression in $\mathrm{H}$ quarters as compared with L quarters.

Our previous investigation in milk cells for $\mathrm{TNF} \alpha$, 5-LO, and COX-2 showed an elevation of mRNA expression during increased immunological activity, which was more distinct than in this study (Wittmann et al., 2002). In this work, differences of SCC between $\mathrm{L}$ and $\mathrm{H}$ quarters were smaller. In our previous investigation SCC were $34 \pm 20 \times 10^{3} / \mathrm{ml}$ and $741 \pm 289 \times$ $10^{3} / \mathrm{ml}$ in $\mathrm{L}$ and $\mathrm{H}$ quarters, respectively, and in this investigation SCC were $64 \pm 18 \times 10^{3} / \mathrm{ml}$ and $445 \pm$ $143 \times 10^{3} / \mathrm{ml}$ in L and $\mathrm{H}$ quarters, respectively. Nevertheless this study verified our previous findings and substantiates the role of milk cells during increased immunological activation. Elevation of COX-2, $\mathrm{TNF} \alpha$ and 5-LO mRNA expression occurs mainly in somatic milk cells. In contrast, mammary tissue is the main source for Lf mRNA. It was previously demonstrated that lactoferrin mRNA expression in bovine mammary tissue is increased after cessation of milking, i.e., when gene expression of other milk proteins is downregulated similarly as during mammary inflammation (Goodman and Schanbacher, 1991).

\section{CONCLUSION}

In conclusion, these results confirm our former finding that the somatic milk cells themselves are involved in the activation and maintenance of immune response in milk on a single quarter level. In addition, the mammary tissue is obviously an important source of synthesis of immunologically and bactericidally active substances. In contrast, in white blood cells none of the factors investigated was significantly changed in animals with partially elevated quarter SCC. This demonstrates that on the level of elevated SCC, but without clinical sign of mammary disease, the immunological activation is to a high degree restricted to the mammary gland without detectable systemic reaction.

\section{ACKNOWLEDGMENTS}

This study was supported by the H. Wilhelm Schaumann-Stiftung, Hamburg, Germany.

\section{REFERENCES}

Arnold, R. R., M. F. Cole, and J. R. Mc Ghee 1977. A bactericidal effect for human lactoferrin. Science 197:263-265.

Arnold, R. R., M. Brewer, and J. J. Gauthier. 1980. Bactericidal activity of human lactoferrin: sensitivity of a variety of microorganisms. Infect. Immun. 28:893-898.

Baggiolini, M., C. De Duve, P. L. Masson, and J. F. Heremans. 1970. Association of lactoferrin with specific granules in rabbit heterophil leukocytes. J. Exp. Med. 131:559-570.

Blum, J. W., H. Dosogne, D. Hoeben, F. Vangroenweghe, H. M. Hammon, R. M. Bruckmaier, and C. Burvenich. 2000. Tumor necrosis factor- $\alpha$ and nitrite/nitrate responses during acute mastitis induced by Escherichia coli infection and endotoxin in dairy cows. Domest. Anim. Endocrinol. 19:223-235.

Bullen, J. J., H. J. Rogers, and E. Griffiths. 1978. Role of iron in bacterial infection. Curr. Top. Microbiol. Immunol. 80:1-35.

Crofford, L. J. 1997. COX-1 and COX-2 tissue expression: implications and predictions. J. Rheumatol. 24:15-19.

Craven, N. 1986. Chemotactic factors for bovine neutrophils in relation to mastitis. Comp. Immun. Microbiol. Infect. Dis. 9:29-36.

Ford-Hutchinson, A. W., M. Gresser, and R. N. Young. 1994. 5Lipoxygenase. Annu. Rev. Biochem. 63:383-417.

German Veterinary Medical Society, DVG e.V., 2000. Leitlinien zur Isolierung und Identifizierung von Mastitiserregern. Verlag der DVG e.V., Bießen, Germany.

Goodman, R. E., and F. L. Schanbacher. 1991. Bovine lactoferrin mRNA: sequence, analysis, and expression in the mammary gland. Biochem. Biophys. Res. Commun. 180:75-84.

Harmon, R. J., and F. H. S. Newbould. 1980. Neutrophil leukocyte as a source of lactoferrin in bovine milk. Am. J. Vet. Res. 41:1603-1606.

Harmon, R. J., F. L. Schanbacher, L. C. Ferguson, and K. L. Smith. 1976. Changes in lactoferrin, immunoglobulin G, bovine serum albumin, and alpha-lactalbumin during acute experimental and natural coliform mastitis in cows. Infect. Immun. 13:533-542.

Heidel, J. R., S. M. Taylor, W. W. Laegreid, R. M. Silflow, H. D. Liggitt, and R. W. Leid. 1989. In vivo chemotaxis of bovine neutrophils induced by 5-lipoxygenase metabolites of arachidonic and eicosapentaenoic acid. Am. J. Pathol. 134:671-676.

Hurley, W. L., and J. J. Rejman. 1993. Bovine lactoferrin in involuting mammary tissue. Cell Biol. Int. 17:283-289.

Kawai, K., S. Hagiwara, A. Anri, and H. Nagahata. 1999. Lactoferrin concentration in milk of bovine clinical mastitis. Vet. Res. Commun. 23:391-398.

Kehrli, M. E., Jr., and D. E. Shuster. 1994. Factors affecting milk somatic cells and their role in health of the bovine mammary gland. J. Dairy Sci. 77:619-627. 
Koenig, W., W. Schoenfeld, M. Raulf, M. Koeller, J. Knoeller, J. Scheffer, and J. Brom. 1990. The neutrophil and leukotrienesrole in health and disease. Eicosanoids 3:1-22.

Liebe, A. 1996. Interrelation between somatic cell counts and concentrations of growth factors, and mastitis in cows kept in different housing systems. PhD Thesis. Techn. Univ. Munich, Germany.

Masson, P. L., J. F. Heremans, J. J. Prignot, and G. Wauters. 1966. Immunohistochemical localization and bacteriostatic properties of an ironbinding protein from bronchial mucus. Thorax 21:538-544.

Nakajima, Y., O. Mikami, M. Yoshioka, Y. Motoi, T. Ito, Y. Ishikawa, M. Fuse, K. Nakano, and K. Yasukawa. 1997. Elevated levels of tumor necrosis factor-alpha (TNF-alpha) and interleukin-6 (IL-6) activities in the sera and milk of cows with naturally occurring coliform mastitis. Res. Vet. Sci. 62:297-298.

Persson, K., I. Larsson, and C. Hallén Sandgren. 1993. Effects of certain inflammatory mediators on bovine neutrophil migration in vivo and in vitro. Vet. Immunol. Immunopathol. 37:99-112.

Pfaffl, M. W., and M. Hageleit. 2001. Validities of mRNA quantification using recombinant RNA and recombinant DNA external calibration curves in real-time RT-PCR. Biotechnol. Lett. $23: 275-282$
Rose, D. M., S. N. Giri, S. J. Wood, and J. S. Cullor. 1989. Role of leukotriene $\mathrm{B}_{4}$ in the pathogenesis of Klebsiella pneumoniaeinduced bovine mastitis. Am. J. Vet. Res. 50:915-918.

Sanchez, M. S., C. W. Ford, and R. J. Yancey Jr. 1994. Effect of tumor necrosis factor- $\alpha$, Interleukin-1 $\beta$, and antibiotics on the killing of intracellular Staphylococcus aureus. J. Dairy Sci. $77: 1251-1258$

SAS, 1995. SAS/STAT User's Guide, release 6.11. SAS Inst. Inc., Cary, NC.

Shuster, D. E., M. E. Kehrli Jr., and M. G. Stevens. 1993. Cytokine production during endotoxin-induced mastitis in lactating dairy cows. Am. J. Vet. Res. 54:80-85.

Smith, W. L., and D. L. Dewitt. 1996. Prostaglandin endoperoxide $\mathrm{H}$ synthases-1 and -2. Adv. Immunol. 62:167-215.

Sordillo, L. M., K. Shafer-Weaver, and D. DeRosa. 1997. Immunobiology of the mammary gland. J. Dairy Sci. 80:1851-1865.

Wittmann, S. L., M. Pfaff, H. H. D. Meyer, and R. M. Bruckmaier. 2002. 5-lipoxygenase, cyclooxygenase-2 and tumor necrosis factor alpha gene expression in somatic milk cells. Milchwiss. 57:63-66.

Zia, S., S. N. Giri, J. Cullor, P. Emau, B. I. Osburn, and R. B. Bushnell. 1987. Role of eicosanoids, histamine, and serotonin in the pathogenesis of Klebsiella pneumoniae-induced bovine mastitis. Am. J. Vet. Res. 48:1617-1625. 